\title{
The Salinity of the Water Retained in the Muddy Foreshore of an Estuary.
}

By

W. B. Alexander, M.A., B. A. Southgate, Ph.D., and R. Bassindale, B.Sc,, From the Laboratory of the Marine Biological Association, Middlesbrough.

Iт has been shown by Reid (1930) that the salinity of the water retained in a sandy foreshore at low tide may be considerably higher than that of a stream of brackish water flowing over it. A few similar observations have been made on the salinity of the water held in the muddy foreshore of the estuary of the River Tees.

The mud banks exposed at low tide are very soft and glutinous, and contain a high percentage of organic matter derived largely from sewage and industrial wastes with which the estuary is polluted.

At low tide, a small hole, some 6 inches deep, was dug in the mud, about 3 feet from the water's edge, and the water which slowly percolated into it was removed in a pipette and filtered. A sample of estuary water was taken at the same time a few feet offshore and the salinity of both samples was determined. The results are shown in the following table, where the average salinity at high water near the estuary bottom at the stations sampled is also given :-

\section{TABLE I.}

$\begin{array}{cccc}\begin{array}{c}\text { Distance from } \\ \text { sea in miles. }\end{array} & \begin{array}{c}\text { Salinity of water } \\ \text { in mud at low tide } \\ \%\end{array} & \begin{array}{c}\text { Salinity of water } \\ \text { offshore at low tide } \\ \%\end{array} & \begin{array}{c}\text { Average salinity of } \\ \text { water at high tide }\end{array} \\ 6 & 28 \cdot 4 & 12 \cdot 6 & \% \\ 6 & 22 \cdot 3 & 14 \cdot 2 & 30 \cdot 0 \\ 10 & 11 \cdot 5 & 0 & 30 \cdot 0 \\ 11 \frac{1}{4} & 5 \cdot 0 & 0 & 25 \cdot 0 \\ & & 0 & 21 \cdot 0\end{array}$

It seems probable that non-burrowing animals living in an estuary are subjected to greater variations and to lower minimum values of salinity than are burrowing forms at the same distance from the sea. It has been observed that, both in the clean, sandy estuary of the Tay, and in the polluted, muddy estuary of the Tees, burrowing marine animals are, on the whole, relatively more abundant in the central part of the estuary than 
non-burrowers. In Table II the number of species of burrowing animals found in each of four sections of the Tees estuary, expressed as a percentage of the total number of burrowing forms present at the estuary mouth, is compared with the corresponding percentage for non-burrowing animals. Similar figures are given for the estuary of the Tay. Owing to the greater length of the Tay estuary, the distances of the lettered sections from the sea are different in the two cases, but the average salinity in any section over all states of the tide is approximately the same in the two estuaries :-

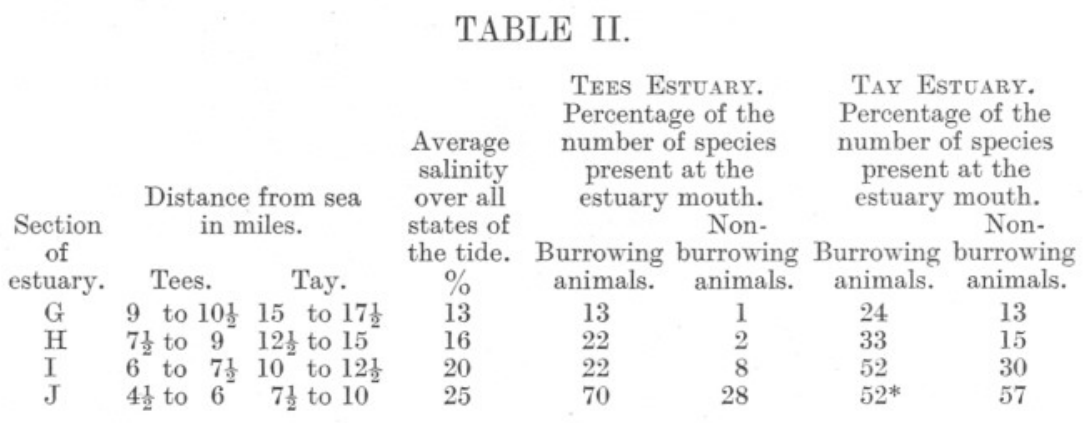

\section{CONCLUSIONS.}

It has been found that the water retained in the muddy foreshore of an estuary at low tide is more saline than the estuary water itself at the same distance from the sea. It is suggested that this retention of salt by the bottom and shore deposits may be a factor favouring the growth of burrowing animals in the central part of an estuary.

The investigation described in this paper was carried out as part of the programme of the Water Pollution Research Board of the Department of Scientific and Industrial Research and is published by permission of the Department.

\section{REFERENCE.}

ReID, D. M. 1930. Salinity Interchange between Sea-Water in Sand and Overflowing Fresh-water at Low Tide. Journ. Mar. Biol. Assoc., N.S., Vol. XVI, No. 2, pp. 609-614.

* This section of the Tay estuary has a steep rocky foreshore, hence comparatively few burrowing animals were found between tidemarks. 